\section{Production and Quality of Physalis ixocarpa Brot. Fruit under Colored Shade Netting}

\author{
Isidro Morales, Gabino Alberto Martínez-Gutiérrez, and \\ Cirenio Escamirosa-Tinoco \\ Instituto Politécnico Nacional (CIIDIR-IPN-Oaxaca), Xoxocotlán, Oaxaca \\ 71230, Mexico
}

\section{Cinthia Nájera}

Centro de Investigación en Biotecnología Agroalimentaria (CIAIMBITAL), Universidad de Almeria, Almeria, Spain

\section{Tatiana Pagan Loeiro da Cunha-Chiamolera \\ Faculdade Campo Real, Guarapuava, Paraná 85015-230, Brasil}

\author{
Miguel Urrestarazu' \\ Departamento de Agronomía, Universidad de Almeria, Almeria, Spain
}

Additional index words. radiation, protection covers, spectrum, commercial yield, husk tomato

\begin{abstract}
The use of colored shade nets is a method to protect plants from direct solar radiation and optimize the light spectra they transmit. The purpose of this work was to evaluate the photosynthetically active radiation $(P A R)$, the photosynthetically active integrated radiation (IPAR), temperature, relative humidity, growth, production, and fruit quality of Physalis ixocarpa variety Tecozautla, cultivated under nets generating $60 \%$ shade in the colors beige, blue, green, red, and black and under a treatment without netting (control group). Different variables were observed: climatic variables, such as radiation, temperature, and relative humidity; growth variables, such as plant height and stem diameter; production variables, such as number, weight, and caliber of the fruit; and quality variables of the fruit, such as $\mathrm{pH}$ and total soluble solids. The highest $P A R$, IPAR, and temperature and lowest relative humidity were obtained in the absence of netting. The white net resulted in the highest $P A R$ and IPAR but no difference in temperature or relative humidity. In addition, an increase in the height, stem diameter, number of branches, and weight, number, and size of the fruit was observed. The white net resulted in the highest yield: $\mathbf{8 8 \%}$ higher than in the control group. The $\mathrm{pH}$ of the fruit was significantly higher under the white netting, and no differences among the treatments in terms of the content of total soluble solids were found.
\end{abstract}

In Mexico, the use of shade nets in protected agriculture has increased. In 2010, 9000 ha were cultivated under shade nets, and in 2016, 38,484 ha were cultivated under shade nets (SAGARPA, 2016). This increase was mainly due to the advantages these nets have compared with plastic, acrylic, and glass covers. These advantages are lower cost, increased durability, and versatility in their use and placement (Valera et al., 2014). They have been successfully used worldwide on tomatoes (Ayala-Tafoya et al., 2011; Valera et al., 2014), cherry tomatoes (Márquez-Quiroz et al., 2014), peppers (Ayala-Tafoya et al., 2014), cranberries (Rodriguez and Morales, 2015), and basil (Martínez-Gutiérrez et al., 2016).

Received for publication 27 Mar. 2018. Accepted for publication $18 \mathrm{Apr}$. 2018.

We thank the Instituto Politécnico Nacional and CONACyT, Mexico, for the projects SIP/ 2015-RE/123 and 248261. We also thank Abraham Gerardo Sánchez-Velasco and José Antonio Maldonado-Patolzin for the field work.

${ }^{1}$ Corresponding author. E-mail: mgavilan@ual.es.
The main objective of shade netting is to modify the radiation that reaches the crop in terms of both quantity and quality. Its placement on the crop decreases the amount of light radiation that strikes the plants during the day, and it also reduces the loss of longwave radiation emitted by the crop during the night (Valera et al., 2014). As a result of these modifications, there is variation in other climatic parameters, such as temperature and the relative humidity of the environment, modifying transpiration, photosynthesis, respiration and other processes in the plants (Shahak and Gussakovsky, 2004; Valera et al., 2014), and decreasing stress to the plants due to biotic and abiotic factors as well as excluding phytopathogenic insects (Ilicì et al., 2014).

Husk tomato ( $P$. ixocarpa Brot. ex Hornem.) is a vegetable native to Mesoamerica whose fruit has been used since the preHispanic era in Mexican gastronomy and traditional medicine (Santiaguillo et al., 2012). Currently, nutraceutical, antibacterial, anticancer, and hypoglycemic properties have been found in the plant. These qualities have caused an increase in demand in Mexico, the United States and Canada (VargasPonce et al., 2015).

In 2015, in Mexico, 43,817 ha were cultivated, with an average yield of 17.34 $\mathrm{t} \cdot \mathrm{ha}^{-1}$ under irrigation and $11.73 \mathrm{t} \cdot \mathrm{ha}^{-1}$ under rainfed conditions (SIAP, 2015). These statistics are considered low because of the scarce research on new technologies, such as the use of protection covers for macro tunnels and greenhouses (Martínez-Gutiérrez et al., 2014), fertirrigation, drip irrigation (López-López et al., 2008), and the lack of commercial cultivars (Fischer et al., 2014). Soldevilla-Canales et al. (2002) obtained 83 $\mathrm{t} \cdot \mathrm{ha}{ }^{-1}$ with padding and the injection of $\mathrm{CO}_{2}$ into the soil, whereas Peña-Lomelí et al. (2014) indicated that to produce greenhouse husk tomato, the problem of pollination must first be solved because of its gametophytic self-incompatibility (Jiménez-Durán and Cruz-García, 2011; Santiaguillo-Hernández et al., 2004).

Because of the socioeconomic importance that the fruit of $P$. ixocarpa has acquired and with the purpose of generating information for their protected cultivation, the objective of this work was to evaluate the effects of shade nets of different colors covering wooden structures on the environmental microclimatic variation, growth, yield, and quality of the fruit of the Tecozautla variety compared with conventional crops.

\section{Materials and Methods}

The research was carried out in Cuilapam de Guerrero, Oaxaca, located at $16^{\circ} 57^{\prime} \mathrm{N}$; $96^{\circ} 45^{\prime} \mathrm{W}$ and an elevation of $1560 \mathrm{~m}$. The crop cycle was from Aug. to Dec. 2015. The Tecozautla variety, which was provided by the National System of Plant Genetic Resources of Mexico (Sistema Nacional de Recursos Fitogenéticos de México), was evaluated. The seeds were sown in 200-well polystyrene trays with a mixture of $80 \%$ sphagnum moss and $20 \%$ perlite. The seedbed was irrigated daily by incorporating 75 , 20, and $75 \mathrm{mg} \cdot \mathrm{L}^{-1}$ of $\mathrm{N}, \mathrm{P}$, and $\mathrm{K}$, respectively, into the water. The experiment was performed in soil in plots $5 \mathrm{~m}$ in width and $10 \mathrm{~m}$ long $\left(50 \mathrm{~m}^{2}\right)$ that contained four rows that were $1 \mathrm{~m}$ wide and $9 \mathrm{~m}$ long. The crop density was two plants $/ \mathrm{m}^{2}$. In each plot, wooden structures $2.0 \times 5.0 \times 10 \mathrm{~m}$ in height, width, and length, respectively, were built; they were covered with shade nets (Fig. 1) of Rashell type and made with high-density polyethylene allowing $60 \%$ shading (Plastimalla Sombra, Mexico) in beige, blue, white, red, and black colors under which the spectrum was also measured (Fig. 2), resulting in an average of three measurements made under the net at a $20-\mathrm{cm}$ distance with a UPRtek MK350S LED Meter (Miaoli, Taiwan). A HD 2302.0 photometer (Delta $\mathrm{OHM}^{\circledR}$, Veneto, Italy) was used to quantitatively measure the light (Urrestarazu et al., 2016). LP 471 $P A R$ and quantum LP 471 PHOT radiometric probes were used to measure the intensity density of the photon flux $\left(\mu \mathrm{mol} \cdot \mathrm{m}^{-2} \cdot \mathrm{s}^{-1}\right)$ and 

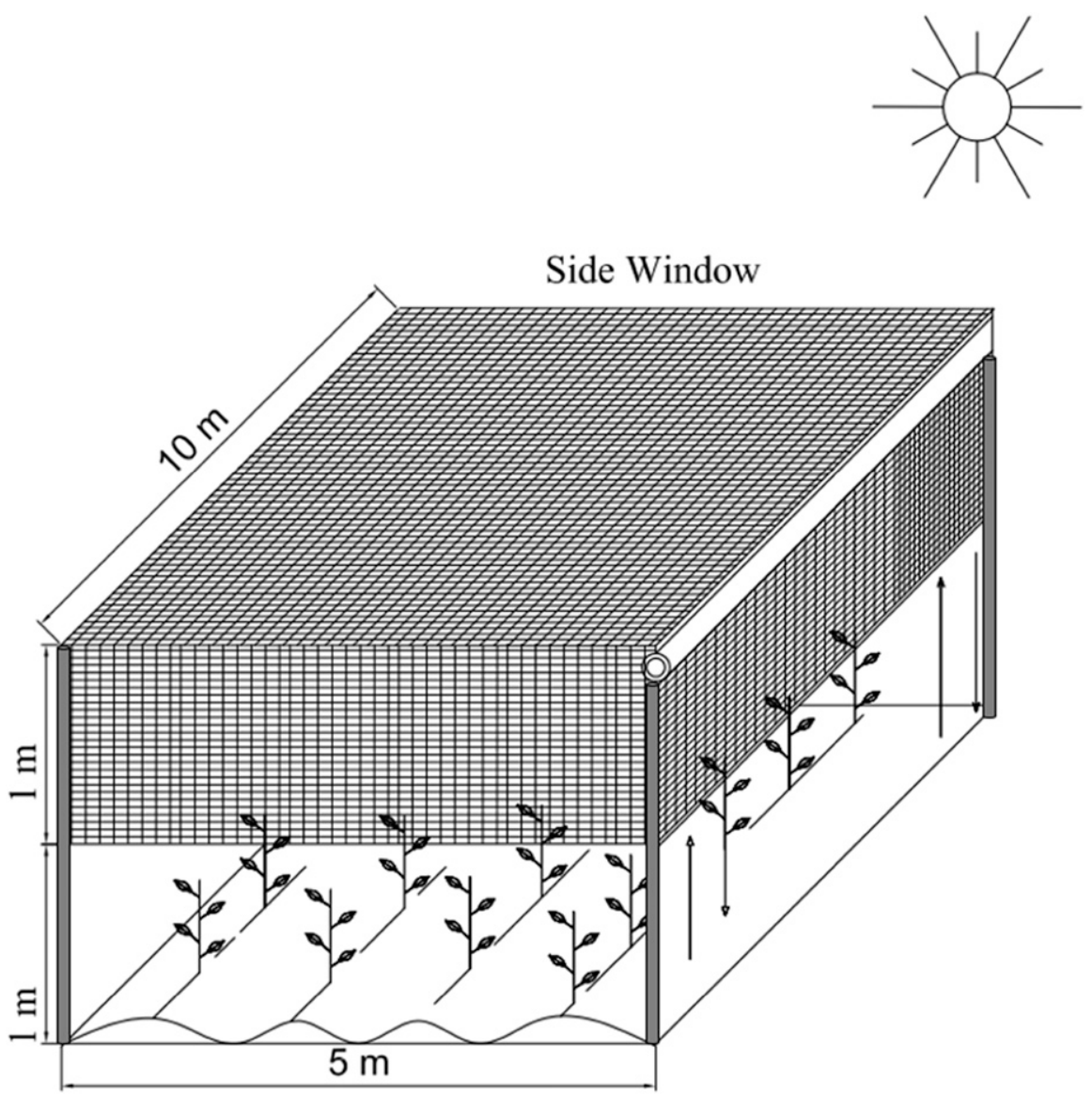

Fig. 1. Wooden structure and area covered with different netting colors used for the cultivation of Physalis ixocarpa Brot. Tecozautla variety.

illuminance (Lux), respectively. These data are shown in Table 1. To allow the entrance and exit of pollinating insects, the lower part of each structure was left uncovered (Fig. 1). Each color corresponded to a treatment, and the control group had no netting (in the field). The experiment was established under a randomized complete block design with three replications. The experimental unit consisted of eight plants.

Drip irrigation was carried out, and the nutrient solution was designed to apply (mg. $\left.\mathrm{L}^{-1}\right) \mathrm{N}(250), \mathrm{P}(60), \mathrm{K}(300), \mathrm{S}(200)$, $\mathrm{Mg}$ (75), Fe (3), Mn (0.5), B (0.5), Cu (0.1), and $\mathrm{Zn}(0.1)$. The $\mathrm{pH}$ values and electrical conductivity (EC) were measured once a week to adjust them to between 5.5 and 6.5 with the addition of nitric acid and between 2.0 and $2.6 \mathrm{dS} \cdot \mathrm{m}^{-1}$, respectively. The $\mathrm{pH}$ was measured with a potentiometer, model 211R (Hanna Instruments ${ }^{\circledR}$ ), and the EC was measured with an EC meter, model 407303 (Extech Instruments ${ }^{\circledR}$ ).

The assessed climatic variables included $P A R \quad\left(\mu \mathrm{mol} \cdot \mathrm{m}^{-2} \cdot \mathrm{s}^{-1}\right)$, which was recorded every other week on sunny days under each shade net and in the absence of netting. The readings were made every hour between 0800 and $1800 \mathrm{HR}$ with a quantum sensor LI-191SA ${ }^{\circledR}$ (LI-COR). Using the average values per hour of $P A R$, the IPAR was measured according to Faust (2002) and
$494 \mu \mathrm{mol} \cdot \mathrm{m}^{2} \cdot \mathrm{s}^{-1}$ in the colors white, beige, red, blue, and black, respectively, and as without netting. The highest $P A R$ was obtained at noon (Fig. 3). The white net decreased the $P A R$ by $50 \%$, whereas the black net decreased the $P A R$ by $68 \%$. These data are similar to the results from the measurements of photon flux intensity performed in the laboratory. In addition, these values are consistent with those reported by Valera et al. (2014) for tomato and pepper crops under shade nets in southeast Spain. Moderate shading of the pepper crop (30\% to $50 \%)$ protected the fruit from sunburn, improving its quality, and for the plant, it reduced the use of water and increased the yield, whereas shading greater than $50 \%$ decreased photosynthesis and productivity (Díaz-Pérez, 2013; Shahak et al., 2008). Ombodi et al. (2015), with the use of nets of different colors in a pepper crop, recorded a reduction of $32 \%$ to $46 \%$ of the $P A R$, decreasing the yield by $23 \%$ to $31 \%$.

Photosynthetically active integrated radiation. During the day, the IPAR had the same tendency as the $P A R$ during all months of cultivation of $P$. ixocarpa (Table 2). The values of the IPAR significantly differed among the colors of the shade nets and no netting. The largest IPAR occurred in October without a net $\left(48.98 \mathrm{~mol} \cdot \mathrm{m}^{2} \cdot \mathrm{d}^{-1}\right)$ and was significantly higher than that obtained under the white shade net in the same month $(25.68$ $\left.\mathrm{mol} \cdot \mathrm{m}^{2} \cdot \mathrm{d}^{-1}\right)$, and it was also under this shade net color that the largest IPAR of the evaluated nets was found during the four months of $P$. ixocarpa cultivation. The lowest IPAR values were found under the black-, blue-, red-, and beige-colored shade nets, and there were no significant differences among them.

Temperature and relative humidity. From October to December, significant differences $(P \leq 0.05)$ in the environmental temperature and relative humidity were found among the colored shade nets and no netting (Table 2). In the absence of nets, the temperature was $2{ }^{\circ} \mathrm{C}$ higher on average and the relative humidity was $4 \%$ lower. The differences between the daytime temperature and relative humidity inside and outside the shade nets were influenced by the characteristics of the covering material, such as its shape and size of the pores and threads (Teitel et al., 2010), as well as the roof cover and the shape and area covered (Möller and Assouline, 2007). Tanny et al. (2009) recorded a lower temperature within shade nets placed horizontally without a vertical cover; this result was similar to that found in the present study.

In January, both the temperature and the relative humidity of the air did not show any differences regardless of the use of nets or under shade nets of different colors; this was a similar observation to that obtained by Ayala-Tafoya et al. (2014), who also did not find any differences in the maximum temperature under colored net covering and no netting in a pepper crop. The lack of a difference in the temperature and relative humidity under different-colored shade nets and no netting was likely because the shade 
A

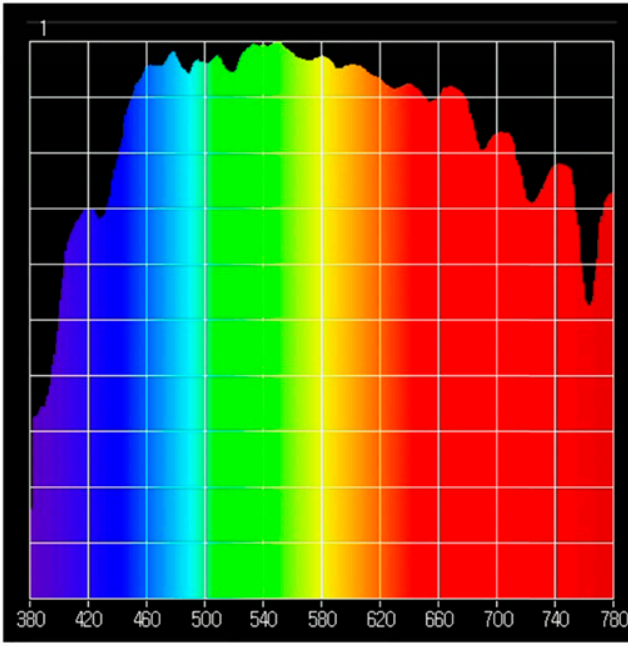

C

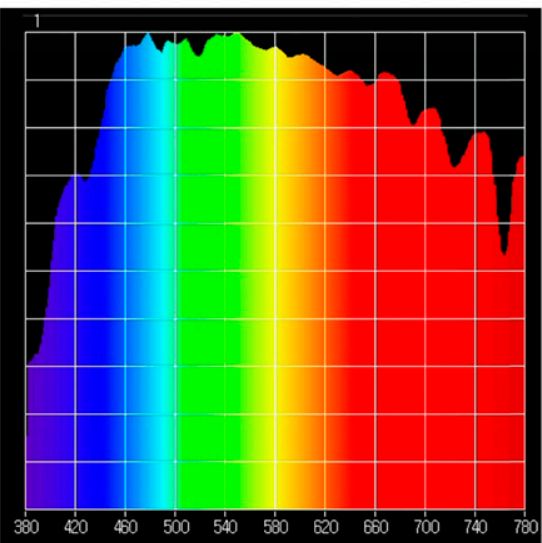

B

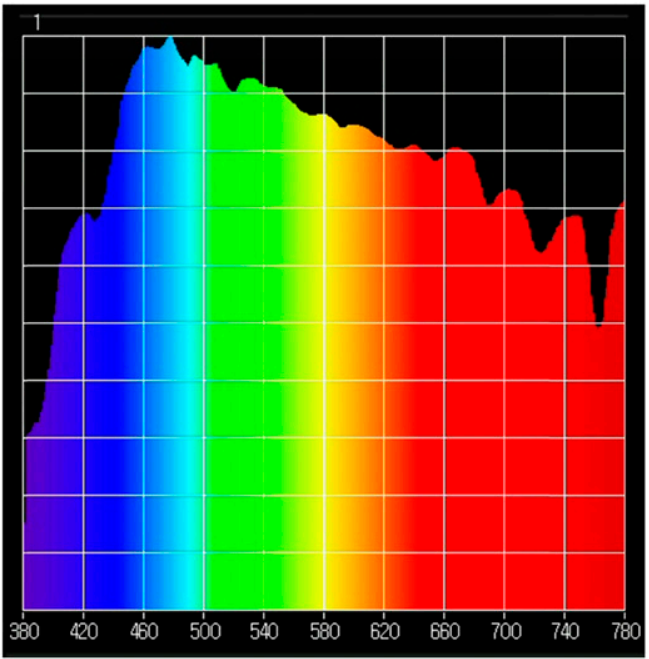

D

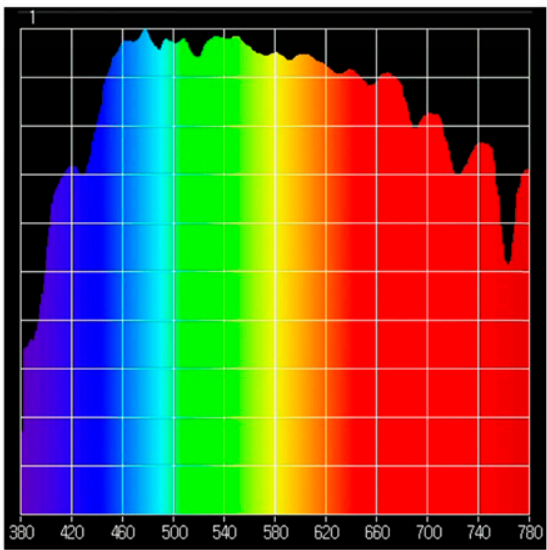

E

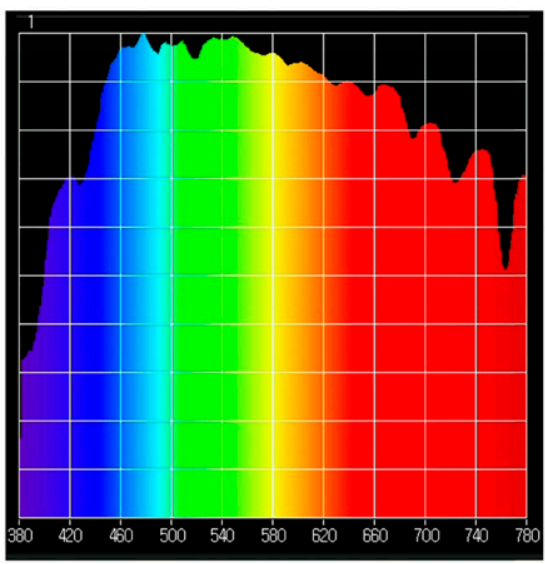

Fig. 2. Spectral photon flux distributions in the netting treatments; (A) beige, $(\mathbf{B})$ blue, $(\mathbf{C})$ white, $(\mathbf{D})$ red, and (E) black.

nets covered only $75 \%$ of the upper part of the structure (Fig. 1).

Morphological and growth variables. The analyses of variance indicate that the colored shade nets and no netting showed significant differences $(P \leq 0.05)$ for all the variables evaluated. The plants cultivated under white shade nets had the highest height, stem diameter, and number of branches, with $141.89,1.29$, and $66.22 \mathrm{~cm}$, respectively (Table 3), whereas the lowest values of these variables were obtained under the red shade net and no netting. These results contradict those obtained by Oren-Shamir et al. (2001) and Shahak et al. (2008), who indicated that the red color stimulates vegetal growth, increasing the vigor of leafy vegetables. Márquez-Quiroz et al. (2014) found a greater plant height with the blue shade net in cherry tomatoes under macro tunnels, whereas Martínez-Gutiérrez et al. (2016) obtained a greater height in basil with the black shade
Table 1. Intensity of the photon flux $\left(\mu \mathrm{mol} \cdot \mathrm{m}^{-2} \cdot \mathrm{s}^{-1}\right)$ and illuminance (Lux) in the netting treatments.

\begin{tabular}{llc}
\hline Netting color & \multicolumn{1}{c}{$P A R$} & Lux \\
\hline Beige & $549 \pm 177$ & $11,778 \pm 1,688$ \\
Blue & $480 \pm 25$ & $17,382 \pm 1,990$ \\
White & $714 \pm 123$ & $18,725 \pm 1,123$ \\
Red & $659 \pm 28$ & $16,485 \pm 1,844$ \\
Black & $530 \pm 42$ & $17,518 \pm 3,564$ \\
\hline
\end{tabular}

Values represent the mean of three replications and standard deviation; $P A R=$ photosynthetically active radiation. 


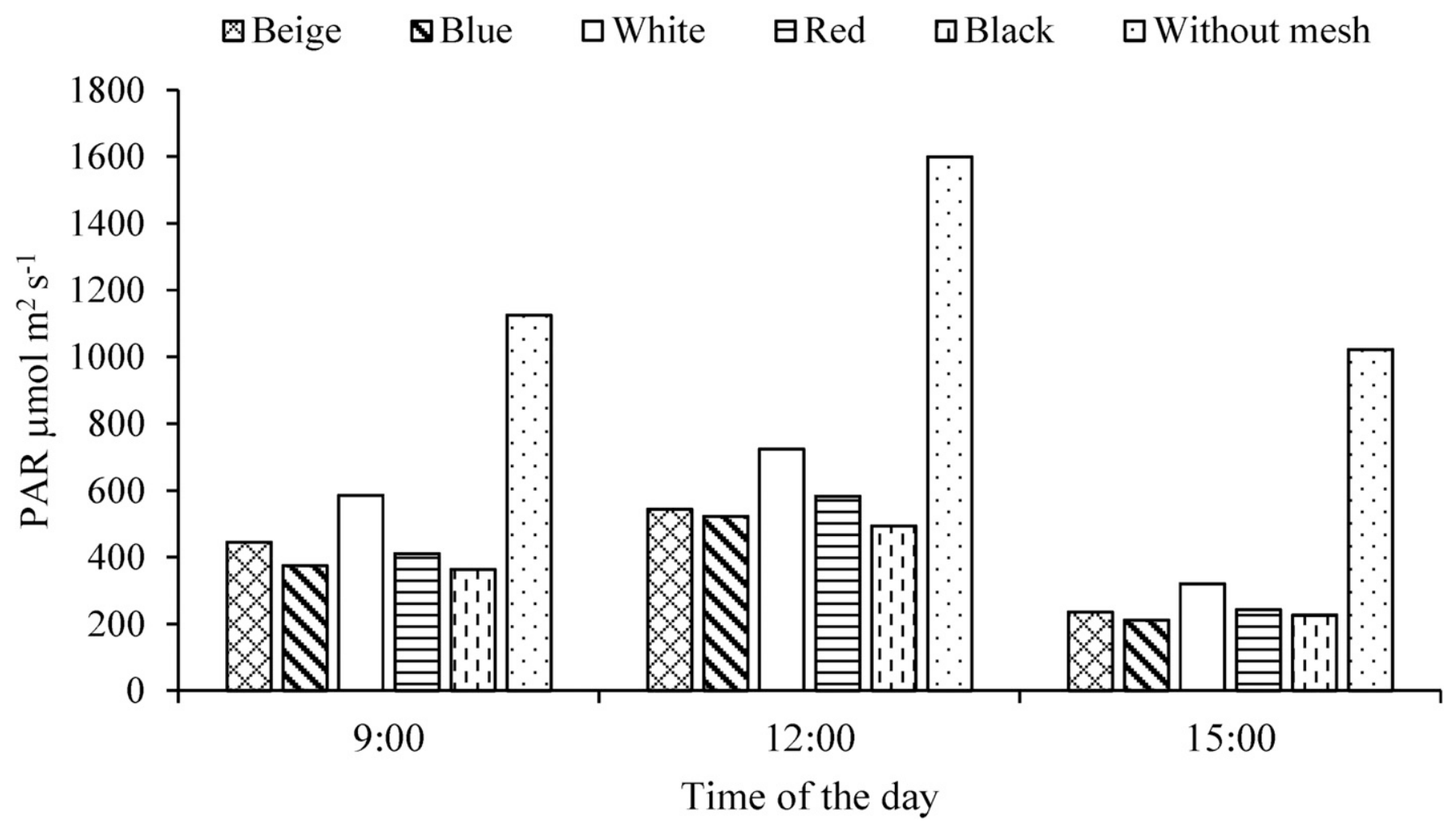

Fig. 3. Photosynthetically active radiation in the interior of wooden structures with different netting colors and without netting.

net. Authors such as Urrestarazu et al. (2016) mentioned that it is important that not only is the quantity of light applied to horticultural crops sufficient for their development but also that the spectral quality favors the growth and organic matter of peppers, tomatoes, and lettuces; specifically, the use of red light vs. white light results in an increase of up to $170 \%$ in the leaf area of tomatoes.

Fruit classification and yield. There were differences among the treatments $(P \leq 0.05)$ in terms of their equatorial and polar diameters, total number of fruits, fruit weight, and total yield. Under the white and blue nets and no netting, the plants produced large fruits with equatorial diameters of 5.28, 5.27 , and $5.32 \mathrm{~cm}$, respectively, which are greater than the equatorial diameters of 4.6 and 3.5 obtained in the P. ixocarpa Tecamac variety by Ponce-Valerio et al. (2012) in a greenhouse. The colors red and black resulted in fruits with smaller equatorial and polar diameters. These results contrast with those obtained by Rodriguez and Morales (2015), who obtained greater equatorial diameters in cranberry fruits under red nets but similar to those in the present study under black shade nets, under which fruits with smaller equatorial and polar diameters were also obtained.

Under the white net, there was a greater total number of fruits per plant; $30 \%$ more than under the other colored nets and no netting. Likewise, the average weight of the fruit and the yield were significantly higher, surpassing the colored nets and no netting by $33 \%$ and $120 \%$, respectively.

Table 2. Integrated photosynthetically active radiation, temperature, and relative humidity in the interior of wooden structures with different netting colors and without netting.

\begin{tabular}{llccc}
\hline Netting color & & & & \\
\hline IPAR $\left(\mathrm{mol} \cdot \mathrm{m}^{-2} \cdot \mathrm{d}^{-1}\right)$ & October & November & December & January \\
\hline Beige & $19.71 \mathrm{c}^{\mathrm{z}}$ & $17.14 \mathrm{c}$ & $16.85 \mathrm{c}$ & $15.96 \mathrm{c}$ \\
Blue & $16.37 \mathrm{c}$ & $14.24 \mathrm{c}$ & $13.03 \mathrm{c}$ & $12.35 \mathrm{c}$ \\
White & $25.68 \mathrm{~b}$ & $22.33 \mathrm{~b}$ & $22.44 \mathrm{~b}$ & $21.26 \mathrm{~b}$ \\
Red & $17.78 \mathrm{c}$ & $15.46 \mathrm{c}$ & $13.98 \mathrm{c}$ & $13.25 \mathrm{c}$ \\
Black & $16.49 \mathrm{c}$ & $14.34 \mathrm{c}$ & $12.80 \mathrm{c}$ & $12.12 \mathrm{c}$ \\
Without netting & $48.98 \mathrm{a}$ & $42.59 \mathrm{a}$ & $40.46 \mathrm{a}$ & $38.33 \mathrm{a}$ \\
CV & 15.22 & 18.41 & 12.55 & 20.04 \\
Temperature $\left({ }^{\circ} \mathrm{C}\right)$ & & & & \\
Beige & $18.50 \mathrm{~b}$ & $18.75 \mathrm{~b}$ & $17.65 \mathrm{~b}$ & $17.29 \mathrm{a}$ \\
Blue & $18.91 \mathrm{~b}$ & $18.16 \mathrm{~b}$ & $17.86 \mathrm{~b}$ & $17.43 \mathrm{a}$ \\
White & $19.05 \mathrm{~b}$ & $18.19 \mathrm{~b}$ & $17.78 \mathrm{~b}$ & $17.40 \mathrm{a}$ \\
Red & $18.60 \mathrm{~b}$ & $18.07 \mathrm{~b}$ & $17.74 \mathrm{~b}$ & $17.30 \mathrm{a}$ \\
Black & $17.92 \mathrm{~b}$ & $17.70 \mathrm{~b}$ & $17.46 \mathrm{~b}$ & $17.11 \mathrm{a}$ \\
Without netting & $20.54 \mathrm{a}$ & $20.04 \mathrm{a}$ & $19.65 \mathrm{a}$ & $18.83 \mathrm{a}$ \\
CV & 10.24 & 12.35 & 11.56 & 8.32 \\
Relative humidity $(\%)$ & & & & \\
Beige & $70.22 \mathrm{a}$ & $70.57 \mathrm{a}$ & $70.59 \mathrm{a}$ & $71.61 \mathrm{a}$ \\
Blue & $71.12 \mathrm{a}$ & $71.03 \mathrm{a}$ & $71.02 \mathrm{a}$ & $71.98 \mathrm{a}$ \\
White & $70.20 \mathrm{a}$ & $70.06 \mathrm{a}$ & $70.50 \mathrm{a}$ & $71.53 \mathrm{a}$ \\
Red & $69.24 \mathrm{a}$ & $69.56 \mathrm{a}$ & $69.43 \mathrm{a}$ & $70.92 \mathrm{a}$ \\
Black & $70.05 \mathrm{a}$ & $70.52 \mathrm{a}$ & $70.31 \mathrm{a}$ & $71.36 \mathrm{a}$ \\
Without netting & $66.32 \mathrm{~b}$ & $66.18 \mathrm{~b}$ & $66.61 \mathrm{~b}$ & $70.06 \mathrm{a}$ \\
CV & 12.87 & 16.04 & 17.62 & 15.46 \\
\hline
\end{tabular}

${ }^{\mathrm{z}}$ Values with the same letter within each column are statistically equal according to the Tukey test $(P \leq$ $0.05)$.

$\mathrm{CV}=$ coefficient of variation.

Fruit quality. Significant differences in fruit quality were observed under the colored nets and no netting (Fig. 4). In general, the fruits produced under the colored nets were less acidic than those produced without netting, being only in this environment that fruits with $\mathrm{pH}$ values close to 4.13 were obtained, which are similar to those obtained by Benito-Bautista et al. (2016) in tomatoes of the Tecozautla variety in a greenhouse but far from the $\mathrm{pH}$ values of 3.93-4.23 obtained by Ramírez-Godina et al. (2013) in P. ixocarpa. The total soluble solids values obtained under shade nets and no netting were lower than the range of 5.27-5.50 reported by Benito-Bautista et al. (2016) and distant from 
Table 3. Morphological variables of Physalis ixocarpa cultivated under different netting colors and without netting.

\begin{tabular}{lccc}
\hline Netting color & Plant ht $(\mathrm{cm})$ & Stem diam $(\mathrm{cm})$ & No. of branches \\
\hline Beige & $123.89 \mathrm{bc}^{\mathrm{z}}$ & $1.10 \mathrm{bc}$ & $51.67 \mathrm{bc}$ \\
Blue & $119.33 \mathrm{c}$ & $1.03 \mathrm{c}$ & $48.78 \mathrm{c}$ \\
White & $141.00 \mathrm{a}$ & $1.29 \mathrm{a}$ & $66.22 \mathrm{a}$ \\
Red & $119.00 \mathrm{c}$ & $1.11 \mathrm{abc}$ & $52.56 \mathrm{bc}$ \\
Black & $126.00 \mathrm{~b}$ & $1.03 \mathrm{c}$ & $57.00 \mathrm{~b}$ \\
Without netting & $112.94 \mathrm{~d}$ & $1.28 \mathrm{abc}$ & $59.39 \mathrm{~b}$ \\
$\mathrm{CV}$ & 1.64 & 6.02 & 12.52 \\
\hline $\mathrm{z}$
\end{tabular}

${ }^{\mathrm{z}}$ Values with the same letter within each column are statistically equal according to the Tukey test $(P \leq$ $0.05)$.

$\mathrm{CV}=$ coefficient of variation.

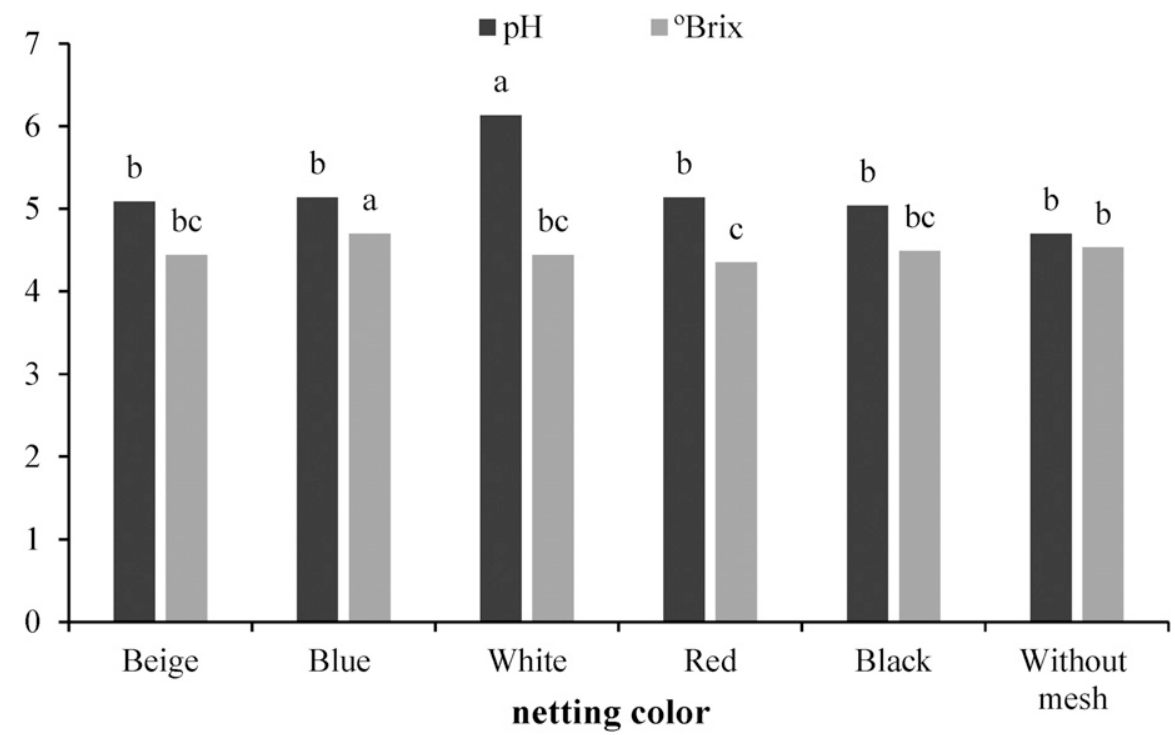

Fig. 4. Fruit quality of Physalis ixocarpa Tecozautla variety cultivated under different netting colors and without netting. Different letters indicate significant differences at the level of $P \leq 0.05$.

the range of 5.95-6.63 found by RamírezGodina et al. (2013). The results obtained for fruit quality indicate that all colored shade nets except the white ones increased the acidity and decreased the total soluble solids of the fruit, properties that are important in the sauce packaging industry and elaboration of sauces.

\section{Conclusions}

Under the colored shade nets, the PAR and IPAR were highest under the white nets, but these values were lower than those obtained in the absence of netting. The relative humidity and environmental temperature behaved similarly under the different-colored nets; in the absence of netting, the temperature was higher and the relative humidity was lower. The height of the plant, the number of fruits and their weight, and the yield increased under the white net. The colors red and black and no netting increased the number of fruits and decreased the fruit size. The white net increased the $\mathrm{pH}$ of the fruit. The total soluble solids of the fruit did not change under the shade nets. The white net can be used as an option to cover structures for the protection and intensive production of Physalis.

\section{Literature Cited}

Ayala-Tafoya, F., R. Sánchez-Madrid, L. Partida-Ruvalcaba, M.G. Yáñez-Juárez, F.H. Ruiz-Espinosa, T.J. Velázquez-Alcaraz, M. Valenzuela-López, and J.M. Parra-Delgado. 2014. Producción de pimiento morrón con mallas sombra de colores. Rev. Fitotec. Mex. 38(1):93-99.

Ayala-Tafoya, F., D.M. Zatarain-López, M. Valenzuela-López, L. Partida-Ruvalcaba, T.J. Velázquez-Alcaraz, T. Díaz-Valdés, and J.A. Osuna-Sánchez. 2011. Crecimiento y rendimiento de tomate en respuesta a radiación solar transmitida por mallas sombra. Terra Latinoam. 29(4):403-410.

Benito-Bautista, P., N. Arellanes-Juárez, and M.E. Pérez-Flores. 2016. Color y estado de madurez del fruto de tomate de cáscara. Agron. Mesoam. 27(1):115-130.

Chang, X., P.G. Alderson, and C.J. Wright 2008. Solar irradiance level alters the growth of basil (Ocimum basilicum L.) and its content of volatile oils. Environ. Expt. Bot. 63:216-223.

Díaz-Pérez, J.C. 2013. Bell pepper (Capsicum annuum L.) crop as affected by shade level: Microenvironment, plant growth, leaf gas exchange, and leaf mineral nutrient concentration. HortScience 48:175-182.

Faust, J.E. 2002. Light management in greenhouses. I. Daily light integral: A useful tool for the U.S. floriculture industry. 6 Jan. 2016. $<$ www.specmeters.com/assets/1/7/ A051.pdf $>$.
Fischer, G., P.J. Almanza-Merchán, and D. Miranda. 2014. Importancia y cultivo de la uchuva (Physalis peruviana L.). Rev. Bras. Frutic. 36(1):1-15.

Ilicì, Z.S., L. Milenkovicì, L. Šunić, D. Cvetkovicì, and E. Fallik. 2014. Effect of coloured shadenets on plant leaf parameters and tomato fruit quality. J. Sci. Food Agr. 95(13):2660-2667.

Jiménez-Durán, K. and F. Cruz-García. 2011. Incompatibilidad sexual, un mecanismo genético que evita la autofecundación y contribuye a la diversidad vegetal. Rev. Fitotec. Mex. 34(1):1-9.

López-López, R., R. Arteaga-Ramírez, M.A. Vázquez-Peña, I.L. López-Cruz, and I. Sánchez-Cohen. 2008. Producción de tomate de cáscara (Physalis ixocarpa Brot.) basado en láminas de riego y acolchado plástico. Rev. Chapingo Ser. Hort. 15:83-89.

Márquez-Quiroz, C., V. Robledo-Torres, and A. Benavides-Mendoza. 2014. Uso de mallas de colores: Una alternativa para la producción de tomate cherry. Ecosist. Recur. Agropecu. 1(2):175-180.

Martínez-Gutiérrez, G.A., R. Díaz-Pichardo, G. Juárez-Luis, Y.D. Ortiz-Hernández, and J.Y. López-Cruz. 2014. Caracterización de las unidades de producción de tomate en invernaderos de Oaxaca. Agr. Soc. Desarro. 11:153-165.

Martínez-Gutiérrez, G.A., L. Nicolás-Santana, Y.D. Ortiz-Hernández, I. Morales, and G.F. Gutiérrez-Hernández. 2016. Crecimiento y contenido de aceite en albahaca (Ocimum basilicum L.) bajo mallas sombra de colores. Interciencia 41(6):428-432.

Möller, M. and S. Assouline. 2007. Effects of a shading screen on microclimate and crop water requirements. Irr. Sci. 25:171-181.

Ombodi, A., Z. Pek, P. Szuvandzsiev, T.Z. Tothne, A. Kohazi-Kis, A. Kovacs, H.D. Ledone, and L. Helyes. 2015. Effects of external coloured shade nets on sweet peppers cultivated in walkin plastic tunnels. Not. Bot. Horti Agrobot. Cluj-Napoca 43(2):398-403.

Oren-Shamir, M., E.E. Gussakovsky, E. Shpiegel, A. Nissim-Levi, K. Ratner, R. Ovadia, Y.E. Giller, and Y. Shahak. 2001. Coloured shade nets can improve the yield and quality of green decorative branches of Pittosporum variegatum. J. Hort. Sci. Biotechnol. 76:353-361.

Peña-Lomelí, A., J.J. Ponce-Valerio, F. Sánchezdel-Castillo, and N. Magaña-Lira. 2014. Desempeño agronómico de variedades de tomate de cáscara en invernadero y campo abierto. Rev. Fitotec. Mex. 37(4):381-391.

Ponce-Valerio, J.J., A. Peña-Lomelí, J.E. RodríguezPérez, R. Mora-Aguilar, R. Castro-Brindis, and L.N. Magaña. 2012. Densidad y poda en tres variedades de tomate de cáscara (Physalis ixocarpa Brot. ex Horm.) cultivado en invernadero. Rev. Chapingo Ser. Hort. 18(3):325-332.

Ramírez-Godina, F., V. Robles-Torres, R Foroughbakhch-Pournabav, A. BenavidesMendoza, J.L. Hérnández-Piñero, M.H. ReyesValdéz, and M.A. Alvarado-Vázquez. 2013. Yield and fruit quality evaluation in husk tomato autotetraploids (Physalis ixocarpa) and diploids. Austral. J. Crop Sci. 7:933-940.

Rodriguez, B.M. and U.D. Morales. 2015. Shading nets effect on the production and quality of blueberry fruit (Vaccinium corymbosum L.) cv. Brigitta. Sci. Agropecu. 6(1):41-50.

SAGARPA (Secretaría de Agricultura Ganaderia, Pesca y Alimentación). 2016. Sistema de información agroalimentaria. 10 Dec. 2016. $<$ http://infosiap.siap.gob.mx/gobmx/datosAbiertos.php>

Santiaguillo, H.J.F., P.O. Vargas, J.O. Grimaldo, L.N. Magaña, V.F.J. Caro, L.A. Peña, and M.J. Sánchez. 2012. Diagnóstico del tomate de 
cáscara. Universidad Autónoma Chapingo, Chapingo, México.

Santiaguillo-Hernández, J.F., T. Cervantes-Santana, and A. Peña-Lomelí. 2004. Selección para rendimiento y calidad de fruto de cruzas planta $\mathrm{x}$ planta entre variedades de tomate de cáscara. Rev. Fitotec. Mex. 27(1):85-91.

SAS (Statistical Analysis System). 2002. SAS/ETS 9 user's guide, Vols. 1 and 2. SAS Institute Inc., Cary, NC, EUA. 2143.

SECOFI (Secretaria de Comercio y Fomento Industrial). 1982. Norma Mexicana NMXFF-54-1982. Productos alimenticios no industrializados para uso humano-hortalizas en estado fresco-tomate con cáscara.

Shahak, Y., E. Gal, Y. Offir, and D. Ben-Yakir. 2008. Photoselective shade netting integrated with greenhouse technologies for improved performance of vegetable and ornamental crops. Acta Hort. 797:75-80.

Shahak, Y. and E.E. Gussakovsky. 2004. ColorNets: Crop protection and light-quality manipulation in one technology. Acta Hort. 659:143-151.

SIAP. 2015. Sistema de información agroalimentaria y pesca. 25 Jan. 2017. <http://www.siap. gob.mx/cierre-de-la-produccion-agricola-porcultivo/>.

Soldevilla-Canales, C.S., A. Peña-Lomelí, M.F Solís-Mendoza, T.R. Vásquez-Rojas, and M.T. Colinas-León. 2002. Aplicación al suelo de $\mathrm{CO}_{2}$, uso de acolchados plásticos y sistemas de manejo en tomate de cáscara (Physalis ixocarpa Brot.). Rev. Chapingo Ser. Hort. $8: 25-38$.

Tanny, J., S. Cohen, A. Grava, A. Naor, and V. Lukyanov. 2009. The effect of shading screens on microclimate of apple orchards. Acta Hort. 807:103-108

Teitel, M., M. Atias, and M. Barak. 2010. Gradients of temperature, humidity and $\mathrm{CO}_{2}$ along a fan-ventilated greenhouse. Biosyst. Eng. 106:166-174.

Urrestarazu, M., C. Nájera, and M. Gea. 2016. Effect of the spectral quality and intensity of light-emitting diodes on several horticultural crops. HortScience 51:268-271.

Valera, D.L., L.J. Belmonte, F.D. Molina, and A. López. 2014. Los invernaderos de Almeria. Análisis de su tecnología y rentabilidad. Cajamar, Almeria, España.

Vargas-Ponce, O., L.E. Valdivia-Mares, and J. Sánchez-Martínez. 2015. Potencial alimenticio de los tomates de cáscara (Physalis spp.) de México. Agroproductividad 8(1):17-23. 